\title{
Providing a psychological scale to measure COVID-19 phobia in the Indonesian version: a brief report on validation of C19P-S via Rasch Analysis
}

\author{
Anastasia Dewi Anggraeni $\left.{ }^{1^{*}}\right)$, Helda Jolanda Pentury², \& Itsar Bolo Rangka ${ }^{3}$ \\ Universitas Indraprasta PGRI ${ }^{123}$ \\ *) Alamat korespondensi: TB. Simatupang, Jl. Nangka Raya No.58 C, Tj Barat, Indonesia; angelinanasta@gmail.com
}

Article History:

Received: 21/02/2021;

Revised: 28/02/2021;

Accepted: 28/02/2021;

Published: 28/02/2021.

How to cite:

Anggraeni, A.D., Pentury, J.H., \& Rangka, I.B. (2021). Providing a psychological scale to measure COVID-19 phobia in the Indonesian version: a brief report on validation of C19P-S via Rasch Analysis. Teraputik: Jurnal Bimbingan dan Konseling, 4(3), pp. 471-481. DOI: $10.26539 /$ teraputik-43586

\begin{abstract}
Specific phobias such as COVID-19 are new and are believed to have developed rapidly since the beginning of the Pandemic established by the WHO in March 2020. Unfortunately, the development of psychological measurement tools related to COVID-19 Phobia is still inadequate in Indonesia. This study aims to validate the Indonesian version of the Phobia scale against COVID-19 (C19P-S). It was recorded that 220 respondents from various groups were involved in this study. The data collected were analyzed by means of the Rasch Model to determine the accuracy of the validated psychometric properties of the scale. The study findings show that the Indonesian version of C19P-S has sufficient psychometric properties and can measure phobia against COVID-19 in the sample group tested. Of the 20 items of the C19P-S, we recommend 18 items that are suitable for use by users of this scale.
\end{abstract}

Keywords: Corona, Phobia; Psychometric Properties; Rasch

Abstrak: Phobia yang spesifik seperti COVID-19 adalah hal yang baru dan dipercaya telah berkembang secara pesat sejak awal Pandemik ditetapkan oleh WHO pada bulan Maret 2020. Sayangnya, pengembangan alat ukur psikologis terkait Phobia COVID-19 masih belum memadai di Indonesia. Studi ini bertujuan untuk memvalidasi skala Phobia terhadap COVID-19 (C19P-S) versi Bahasa Indonesia. Tercatat 220 responden dari berbagai kelompok dilibatkan dalam studi ini. Data yang dikumpulkan dianalisis dengan Rasch Model untuk menentukan akurasi properti psikometrik skala yang divalidasi. Temuan studi menunjukkan bahwa C19P-S versi Bahasa Indonesia memiliki properti psikometrik yang memadai dan dapat untuk mengukur phobia terhadap COVID-19 pada kelompok sampel yang diujikan. Dari 20 item C19P-S, kami merekomendasikan 18 item yang fit untuk digunakan oleh para pengguna skala ini.

Kata Kunci: Corona, Phobia; Properti Psikometrik; Rasch distributed under the Creative Commons 4.0 Attibution License, which permits unrestricted use, distribution, and reproduction in any medium, provided the original work is properly cited. (C) 2021,

Anastasia Dewi Anggraeni,

Helda Jolanda Pentury, \& Itsar Bolo Rangka (s).

\section{Introductions}

In 2020 is a very painful year for countries in the world due to the spread of Corona Virus Disease 2019 (COVID-19). Various policies have been taken by countries affected by COVID-19 as a response measure and to reduce the rate of spread of COVID-19 including shutting down and limiting human activities (physical distancing, self-isolation and social distancing) and following the health protocol campaign issued by the World Health Organization (WHO). From various points of view, COVID-19 has drained a lot of energy, focus and resources from each country to reduce the impact felt by its people in different sectors of life since it was first discovered in December 2019 in Wuhan Province, China.

In Indonesia, the first case of COVID-19 was recorded on March 2, 2020, where two Indonesian citizens (a 31-year-old woman and a 64-year-old mother) tested positive for COVID19 after making contact with Japanese nationals who came to Indonesia. This fact was 
472 Providing a psychological scale to measure COVID-19 phobia in the Indonesian version: a brief report on validation of C19P$\mathrm{S}$ via Rasch Analysis

announced directly by the President of the Republic of Indonesia, Ir. H. Joko Widodo. This fact triggers a sense of "panic" and great concern in the community regarding the possible to be infected with COVID-19. Since then, the Government of Indonesia has begun to take concrete steps in the form of a policy called Large-Scale Social Restrictions (PSBB) throughout Indonesia and has re-focused Government activities to minimize the spread of COVID-19. There are three core protocols in the PSBB period, namely restrictions on entry permits (travel) to and from the territory of Indonesia; restrictions on the use of public transportation; and restrictions on face-toface learning activities in educational institutions.

From March to October 9, 2020, the number of positive cases of COVID-19 in Indonesia that were confirmed through the Task Force for the Acceleration of Handling COVID-19 reached 324,658 peoples; where 247,667 peoples were declared cured, and 11,677 people died. The highest positive cases of COVID-19 are in the DKI Jakarta and its surrounding areas, namely Depok, Tangerang, Bogor, and Bekasi (Jabodetabek), which account for nearly $30 \%$ of the national cumulative total. As an area with a high population density, the number of schools in the Jabodetabek area is also the highest so that the potential for transmission is also estimated to be the highest. As a result, every individual in the Jabodetabek area is urged to increase awareness and follow the Health Protocol (PSBB) to prevent COVID-19.

During the PSBB period, Indonesian Government instructions such as, "Work from Home $(\mathrm{WfH})$ and" Study from Home $(\mathrm{SfH})$ "became very familiar and popular among the community. However, this poses a problem in itself where the transition to work and study from home forces everyone to make radical changes in their life. The shifting of life habits, whether at work or studying from home, coupled with the erratic conditions of the COVID-19 Pandemic, are tough and cause psychological health problems for the community.

The serious negative physiological, social and economic effects of the COVID-19 pandemic have been observed in many countries. These negative effects lead to conditions including stress, depression, psycho-somatic, and psycho-social disorders (Arpaci et al., 2020). Study conducted Daly et al. (2021) shows an increase in cases of depression during the COVID-19 pandemic in the U.S. Although it is known that health professionals are the group most at risk of experiencing psychological disorders (da Silva \& Neto, 2021), however, this does not mean that non-health professionals are safer from the disorder. Study conducted by Ruiz-Frutos et al. (2021) shows that $71.6 \%$ of non-health female workers and $52.4 \%$ of male non-health workers experienced psychological distress during the COVID-19 pandemic. This shows that psychological health problems are a crucial point where solutions need to be sought, including synergies for handling inaccurate news related to the COVID-19 pandemic on social media which directly affects psychological health conditions (Zhong et al., 2021).

Psychological health measurement tools have been developed. Several measuring instruments or psychological scales were developed based on needs and adapted to the world situation and the development of psychology itself. Unfortunately, there is little empirical support for this category of specific phobias (Muris et al., 1999). Realizing how strong the influence of the COVID-19 Pandemic is on a person's psychological health, action is needed to identify the problem. At the practical level, the development of measuring instruments or psychological scales to measure specific phobias such as COVID-19 requires a long time. However, this does not mean it is impossible.

In the midst of the current pandemic situation, there are alternative ways that can be taken by developers of measuring instruments or psychological scales, namely adapting the scale. Several psychological scales developed to measure the relationship between the COVID-19 situation and the incidence of psychological disorders in humans have been available in various worlds such as (1) The Fear of COVID-19 Scale (Ahorsu et al., 2020; Reznik et al., 2020; Satici et al., 2020; Soraci et al., 2020), (2) Coronavirus Anxiety Scale (Chandu et al., 2020; Evren et al., 2020; Lee, 2020; Lee et al., 2020), (3) Stress of COVID-19 Scale (Feng et al., 2020; Pakpour et al., 2020), (4) COVID-19 Perceived Risk Scale (Yıldırım \& Güler, 2020). Psychological disorders such as fear, anxiety, stress, and depression regarding COVID-19 have a special connection with specific phobic disorders, however the availability of measuring instruments or psychological scales for COVID-19 Phobia has only been documented by Arpaci et al. (2020), and has not been 
found in Indonesian. The availability of the Phobia COVID-19 scale in the Indonesian version that meets the standards is expected to help users identify the level of specific psychological disorders (phobia) related to COVID-19.

Based on the previous description, this study aims to develop and adapt the Indonesian version of the Phobia scale against COVID-19. This research is also expected to provide empirical evidence of the results of language translation, psychometric validation and the development of the Indonesian version of the COVID-19 Phobia Scale (C19P-S).

\section{Method}

This study uses a quantitative approach and was carried out in September 2020 - January 2021. The translation procedure begins with a study of the latest literature related to phobia to COVID-19. Furthermore, the adaptation process of this scale involves one psychometric expert to weigh the instrument content qualitatively, and an Indonesian expert for the linguistic aspects used. Weighing the scale is done quantitatively with a limited field trial mechanism. Testing of the instrument in the Indonesian version was carried out on a limited basis and continued more broadly as the sample group was targeted in this study.

Data collection and instrument deployment are carried out with the help of Google Form. Furthermore, the data collection process also involved several volunteers assigned to designated area points to ensure data distribution was spread out and represented the needs of the research being carried out. Before collecting data, the respondents were given information and an introduction from the research team. There is no compulsion for respondents to participate in this research, and; all personal information of respondents is credential.

The COVID-19 Phobia Scale (C19P-S) developed by Arpaci et al. (2020) is the scale used in the translation and validation process in this study. C19P-S contains 20 items covering respondent responses regarding the presence or absence of disorders (1) Psychological, (2) Psycho-somatic, (3) Economic, and (4) Social.

Study conducted by Arpaci et al. (2020) shows that shows that C19P-S has good evidence of construct validity, convergent, discriminant, and internal consistency reliability. The C19P-S is a self-report instrument with fve-point Likert-type scale to assess the levels of coronavirus (COVID-19) phobia. All items are rated on a 5-point scale from "strongly disagree (1)" to "strongly agree (5)."

This study involved 220 respondents who were taken randomly and came from several regions in Indonesia. We mapped them into certain demographic aspects, such as age, gender, area of origin, exercise routine in one week, and experience of carrying out a Covid-19 test. The distribution of demographic aspects of the participants is presented in Table 1.

Table 1. Distribution of Participants based on Demographic Aspects

\begin{tabular}{lcccccc}
\multicolumn{1}{c}{ Aspek } & $\mathrm{N}$ & $(\%)$ & Mean & S.E & S.D & Reliability \\
\hline Gender & & & & & & \\
$\quad$ Female & 140 & 63.6 & .83 & .08 & .87 & .88 \\
$\quad$ Male & 80 & 4 & .64 & .19 & 1.61 & .93 \\
Age & & 36.3 & & & & \\
$\quad$ Under 25 Years Old & 208 & 6 & .74 & .09 & 1.18 & .91 \\
$\quad$ Above 25 Years Old & 12 & & 1.23 & .43 & 1.36 & .92 \\
Domicile & & 94.5 & & & & \\
$\quad$ Banten & 4 & 5 & .03 & .40 & .64 & .86 \\
$\quad$ Jakarta & 45 & 5.45 & .87 & .17 & 1.09 & .92 \\
Jawa Barat & 54 & & .53 & .08 & .51 & .78 \\
$\quad$ Jawa Tengah & 4 & 1.82 & .35 & .50 & .83 & .90 \\
$\quad$ Nusa Tenggara Timur & 20 & 20.4 & 1.53 & .35 & 1.45 & .88 \\
Papua & 36 & 5 & .94 & .20 & 1.15 & .92 \\
$\quad$ Papua Barat & 47 & 24.5 & .54 & .25 & 1.64 & .92 \\
$\quad$ Sulawesi Selatan & 10 & 5 & .82 & .31 & .88 & .90 \\
\hline
\end{tabular}


474 Providing a psychological scale to measure COVID-19 phobia in the Indonesian version: a brief report on validation of C19P$\mathrm{S}$ via Rasch Analysis

\begin{tabular}{|c|c|c|c|c|c|c|}
\hline Marital Status & & 1.82 & & & & \\
\hline Married & 11 & 9.09 & .68 & .26 & .78 & .88 \\
\hline Unmaried & 209 & 16.3 & .77 & .09 & 1.22 & .91 \\
\hline Divorced & 0 & 6 & 0 & 0 & 0 & 0 \\
\hline Sports Exercise Per Week & & 21.3 & & & & \\
\hline Never & 47 & 6 & .93 & .16 & 1.01 & .91 \\
\hline Once in a week & 100 & 4.55 & .60 & .14 & 1.34 & .91 \\
\hline Twice a week & 33 & & .81 & .17 & .90 & .90 \\
\hline Three times a week & 17 & 5.00 & 1.01 & .32 & 1.24 & .91 \\
\hline More than three times a week & 23 & 95.0 & .87 & .26 & 1.18 & .92 \\
\hline Experiences on Covid-19 Test & & 0 & & & & \\
\hline Never & 146 & 0.00 & .76 & .12 & 1.33 & .91 \\
\hline Yes on Rapid Test Antibody & 46 & & .91 & .15 & .93 & .86 \\
\hline Yes on Rapid Test Antigen & 12 & 21.3 & .58 & .30 & .95 & .92 \\
\hline Yes on PCR Test & 16 & 6 & .47 & .14 & .47 & .76 \\
\hline & & 45.4 & & & & \\
\hline & & 15.0 & & & & \\
\hline & & 0 & & & & \\
\hline & & 7.73 & & & & \\
\hline & & 10.4 & & & & \\
\hline & & 5 & & & & \\
\hline & & 66.3 & & & & \\
\hline & & 6 & & & & \\
\hline & & 20.9 & & & & \\
\hline & & 1 & & & & \\
\hline & & 5.45 & & & & \\
\hline & & 7 & & & & \\
\hline
\end{tabular}

Note: Mean, S.E., S.D., and Reliability are based on the calculation of the respondent's Covid-19 Phobia Score in the Rasch Model computation.

The initial stage of data analysis was carried out by scanning with the aim of seeing the quality of the data that had been collected. The quality of research data is determined by how big the respondents are outliers. Furthermore, the main analysis of this study was carried out with the Rasch modeling to provide an estimate of the psychometric properties of the Indonesian version of the COVID-19 Phobia Scale which includes (1) item and person reliability; (2) unidimensionality and rating scale analysis; (3) items and person difficulties; (4) biases item based on differential items functioning.

\section{Result and Discussions}

There is a large part of which is the subject of the validation process for the Indonesian version of the C19P-S.

\section{Initial Screening}

In this section we conduct an investigation to see the quality of the data that has been collected. The aim is to check the pattern of responses given by respondents to the C19P-S items that have been given, and also the appropriateness of the items. In the Rasch Model, the accuracy of the data collected and the suitability of the data to the ideal model are in the Outfit value range of 0.5 - 1.5 logit, where items and persons who have values outside that range can be detected as outliers (Sumintono \& Widhiarso, 2014). The results showed that out of 220 respondents who filled in C19P-S, there were 100 respondents who gave inappropriate responses (outliers). 
Meanwhile, of the 20 items C19P-S only 1 item (No.6 - "Saya jengkel dengan orang-orang yang mengabaikan bahaya penyebaran virus corona") including items that are outliers.

This empirical fact shows us that almost $50 \%$ of respondents tend to give "wrong" responses than they should. This also prompted us to use only 120 respondents and 19 C19P-S items for further analysis.

\section{Reliabilities Item and Person}

The C19P-S computation ( $N=120, I=19$ ) shows that the reliability value of C19P-S for items (.99) and persons (.90) is in the very high category, with a Cronbach $=.90$. This shows that the items used in C19P-S have the ability to accurately define latent traits, namely Covid-19 phobia. Likewise, the reliability of the person indicates that there is consistency in the response pattern given by all respondents who fill in the C19P-S.

Another important finding that is also presented in this section is that the Separation Index value is able to classify the ability of respondents into three clusters (3.07) and 8 clusters (8.82) for C19P-S items. This indicates that both persons or items can properly map the conditions and levels of phobia experienced by the respondents with Covid-19.

\section{Unidimensionality and Rating Scale Analysis}

Unidimensionality test on C19P-S aims to evaluate whether the instrument which has developed are able to measure the measureable thing such as Phobia Covid-19. Table 2 shows that Raw Variance Explained by Measures as 60,6\%, means that Unidimensionality condition of C19P-S is sufficient. On the other hand, C19P-S can be used to measure the scale of Phobia Covid-19.

Table 2. Raw Residual variance in Eigenvalue units of C19P-S (N=120, I=19)

\begin{tabular}{clll}
\hline & Eigenvalue & Observed & Expected \\
\hline Total raw variance in observations & 48.1623 & $100.0 \%$ & $100.0 \%$ \\
Raw variance explained by measures & 29.1623 & $60.6 \%$ & $60.2 \%$ \\
Raw variance explained by persons & 9.8751 & $20.5 \%$ & $20.4 \%$ \\
Raw Variance explained by items & 19.2872 & $40.0 \%$ & $39.8 \%$ \\
Raw unexplained variance (total) & 19.0000 & $39.4 \%$ & $39.8 \%$ \\
Unexplned variance in 1st contrast & 3.4950 & $7.3 \%$ & $18.4 \%$ \\
Unexplned variance in 2nd contrast & 2.3074 & $4.8 \%$ & $12.1 \%$ \\
Unexplned variance in 3rd contrast & 1.9117 & $4.0 \%$ & $10.1 \%$ \\
Unexplned variance in 4th contrast & 1.4562 & $3.0 \%$ & $7.7 \%$ \\
Unexplned variance in 5th contrast & 1.3501 & $2.8 \%$ & $7.1 \%$ \\
\hline
\end{tabular}

Furthermore, the results of the rating scale analysis test show that the alternative answers offered in the Indonesian version of C19P-S are good and do not cause specific confusion for the respondents. Appendix I shows that empirically, there is an increase in the dynamic andrich threshold value.

\section{Items and Persons Difficulties}

In this section we test the difficulty level of items and people. Items difficulties aim to evaluate the level of items from the most difficult to the easiest. Table 3 shows that Item No. 8 "Kekhawatiran saya terhadap virus corona membuat saya sulit bernafas" (+2.18 logit) is the item most difficult to agree on by all respondents who filled out C19P-S. Instead, Item No. 2 "Saya cemas jika ada keluarga dekat saya terinfeksi virus corona" (-1.80 logit). 
476 Providing a psychological scale to measure COVID-19 phobia in the Indonesian version: a brief report on validation of C19P$\mathrm{S}$ via Rasch Analysis

Table 3. Mapping the difficulty level of C19P-S items $(\mathrm{N}=120, \mathrm{I}=19)$

\begin{tabular}{ll}
\hline No & \multicolumn{1}{c}{ Aitem of C19P-S } \\
\hline 8 & ID = Kekhawatiran saya terhadap virus corona membuat saya sulit bernafas \\
& EN = My concern about the corona virus makes it difficult for me to breathe \\
10 & ID = Saya mengalami gangguan tidur karena kondisi pandemik virus corona \\
& EN = I have sleeping disorder due to the corona virus pandemic condition \\
9 & ID = Memikirkan virus corona membuat saya sakit kepala \\
7 & $\begin{array}{l}\text { EN = Thinking of the coronavirus gives me a headache } \\
\text { ID = Memikirkan virus corona membuat perut / kondisi pencernaan saya } \\
\text { terganggu }\end{array}$ \\
EN = Thinking of the corona virus upset my stomach / digestive condition \\
ID = Saya membeli bahan makanan yang cukup banyak untuk cadangan \\
kebutuhan hidup saya jika kondisi pandemi virus corona ini semakin \\
memburuk
\end{tabular}

Measure

$15 E N=$ I bought enough food to spare for my living needs if the corona virus pandemic conditions got worse

ID = Saya kuatir kebutuhan hidup saya tidak tercukupi selama pandemi virus corona berlangsung.

$16 \mathrm{EN}=\mathrm{I}$ am worried that my life needs will not be fulfilled during the corona virus pandemic.

ID = Pandemi virus corona membuat saya mudah cemas ketika melihat orang lain batuk.

$11 \mathrm{EN}=$ The coronavirus pandemic makes it easy for me to worry when I see -.19 other people coughing.

ID = Aktivitas fisik yang biasanya mudah saya lakukan menjadi sulit ketika pandemi virus corona melanda lingkungan saya.

$12 \mathrm{EN}=$ The physical activity that I usually do easily becomes difficult when the corona virus pandemic hits my neighborhood.

$\mathrm{ID}=$ Saya kuatir pandemi virus corona yang terus berlangsung akan - .22

20 mengakibatkan krisis bahan makanan

$\mathrm{EN}=\mathrm{I}$ am worried that the ongoing corona virus pandemic will result in a food crisis

ID = Dalam periode pandemi virus corona, sulit bagi saya untuk merasa

5 rileks jika jarak (fisik) saya dengan orang lain terlalu dekat

2.18

2.05

1.94

1.78

.60

.22

.08

$\mathrm{EN}=$ In the pandemic period of the coronavirus, it is difficult for me to relax

17 if my (physical) distance from other people is too close

ID = Penyebaran virus corona yang begitu cepat membuat saya panik

$\mathrm{EN}=$ The spread of the corona virus so fast makes me panic

13 ID = Sedapat mungkin saya berupaya menghindari orang yang saya lihat - .53 mengalami bersin-bersin.

$\mathrm{EN}=$ As much as possible I try to avoid the people, I see sneezing.

ID = Saya cemas alat-alat kesehatan/pengobatan/pelindung diri semakin

19 sulit terjangkau di periode pandemi virus corona

$\mathrm{EN}=\mathrm{I}$ am worried that medical / medical / personal protective equipment will become increasingly difficult to reach in the period of the corona virus pandemic

$4 \quad$ ID = Pandemi virus corona membuat saya menghindari bertemu orang secara langsung (tatap muka secara fisik)

$\mathrm{EN}=$ The corona virus pandemic keeps me from meeting people in person (face to face physically)

$3 \quad$ ID = Ketidakpastian informasi terkait virus corona membuat perasaan saya $\quad-1.15$ menjadi cemas 


\begin{tabular}{|c|c|c|}
\hline No & Aitem of C19P-S & Measure \\
\hline 18 & $\begin{array}{l}\text { EN = The uncertainty of information regarding the corona virus makes me } \\
\text { feel anxious } \\
\text { ID = Saya merasa tidak nyaman dengan berita kematian akibat virus corona } \\
\text { EN = I feel uncomfortable with the news of the death from the corona virus } \\
\text { ID = Saya takut terinfeksi virus corona } \\
\text { EN = I am afraid of being infected with the corona virus }\end{array}$ & -1.43 \\
\hline 2 & $\begin{array}{l}\text { ID = Dalam situasi pandemi virus corona, saya lebih memperhatikan } \\
\text { kebersihan tangan saya jauh dari biasanya. } \\
\text { EN = In the coronavirus pandemic situation, I pay more attention to my hand } \\
\text { hygiene than usual. } \\
\text { ID = Saya cemas jika ada keluarga dekat saya terinfeksi virus corona } \\
\text { EN = I am worried if my close family is infected with the corona virus }\end{array}$ & -1.80 \\
\hline
\end{tabular}

Meanwhile, in the evaluation of persons abilities, it is known that Person No. 100 (100 M B PB UM B Never) is the person who has the highest level of phobia towards Covid-19 (+5.88 logit) when compared to other respondents. Instead, Person No. 84 (84 UM E Yes RT Antigen) is the person with the lowest phobia level towards Covid-19 (-1.04 logit). Information regarding the persons abilities distribution is presented in full in Appendix II of this article.

\section{Differential Items Functioning (DIF)}

Another important point of this study is to evaluate whether the items in the C19P-S are biased towards certain demographic groups. We include six demographic aspects in this study, namely (1) Gender, (2) Age, (3) Domicile, (4) Marital Status, (5) Sports Exercise Per Week, and; (6) Experiences on Covid-19 Test. Differential Items Functioning (DIF) item is identified if Prob. $<.05$. DIF analysis on the demographic aspects of the C19P-S 01 results there is no. That is, the potential DIF of the item is not identified. However, the sports exercise per week in point number 10, shows a DIF .0151.

Table 4 shows that of the 6 demographic aspects, item No. 10 "Saya mengalami gangguan tidur karena kondisi pandemik virus corona" which is biased towards one particular demographic aspect, namely Sports Exercise Per Week. Table 4 in detail shows that the phobic response pattern to Covid-19 does not work well with the respondents' length of exercise.

Table 4. DIF details on Sports Exercise Per Week ( $N=120$, Item Number 10)

\begin{tabular}{|c|c|c|c|}
\hline Aspect & Compared to & DIF Prob. & DIF Contrast \\
\hline \multirow[t]{4}{*}{ Never } & Once in a week & .0600 & -.70 \\
\hline & Twice a week & .5284 & -.56 \\
\hline & Three times a week & .1573 & .88 \\
\hline & $\begin{array}{l}\text { More than three times a } \\
\text { week }\end{array}$ & 1.000 & .38 \\
\hline \multirow[t]{4}{*}{ Once in a week } & Never & .0600 & .70 \\
\hline & Twice a week & .4056 & .14 \\
\hline & Three times a week & .1934 & 1.58 \\
\hline & $\begin{array}{l}\text { More than three times a } \\
\text { week }\end{array}$ & .0435 & 1.08 \\
\hline \multirow[t]{4}{*}{ Twice a week } & Never & .5284 & .56 \\
\hline & Once in a week & .4056 & -.14 \\
\hline & Three times a week & .3173 & 1.44 \\
\hline & $\begin{array}{l}\text { More than three times a } \\
\text { week }\end{array}$ & .5271 & .94 \\
\hline
\end{tabular}


478 Providing a psychological scale to measure COVID-19 phobia in the Indonesian version: a brief report on validation of C19P$\mathrm{S}$ via Rasch Analysis

\begin{tabular}{llll} 
Three times a week & Never & .1573 & -.88 \\
& Once in a week & .1934 & -1.58 \\
& Twice a week & -1.44 \\
& $\begin{array}{l}\text { More than three times a } \\
\text { week }\end{array}$ & .3173 & -.50 \\
& & & \\
More than three times a & Never & 1.000 & -1.08 \\
week & Once in a week & .0435 & -.94 \\
& Twice a week & .5271 & .50 \\
& Three times a week & .3173 & .79 \\
\hline DIF item were identified if Prob. $<.05$ and DIF Contrast $>.43$ for each item in certain demographic aspects.
\end{tabular}

Table 4, the group of respondents who had sports activities once and more than three times a week gave different responses (bias). This indicates that Item No. 10 in the Indonesian version of the C19P-S does not work well for both groups of respondents.

After going through the initial screening, reliabilities item and person, unidimensionality and rating scale analysis, items and persons difficulties, \& Differential Items Functioning (DIF), the COVID-19 Phobia Scale (C19P-S) can be used among the general public. Further researcher's suggestion is to be able to use this COVID-19 Phobia Scale (C19P-S) for applied research.

\section{Conclusions}

The COVID-19 Phobia Scale (C19P-S) has been successfully adapted and validated into the Indonesian version. The main findings in this study indicate that C19P-S has sufficient psychometric properties to measure the level of Covid-19 phobia. Practically, some important notes in this study that need to be considered by users are the C19P-S which can be used as many as 18 items, from 20 items of C19P-S. Furthermore, this study has quite high respondent outliers, for that reason, a re-validation process for a larger scale may be required as a comparative study of the findings of this study.

\section{Daftar Rujukan}

Ahorsu, D. K., Lin, C. Y., Imani, V., Saffari, M., Griffiths, M. D., \& Pakpour, A. H. (2020). The Fear of COVID-19 Scale: Development and Initial Validation [Article]. International Journal of Mental Health and Addiction. https://doi.org/10.1007/s11469-020-00270-8

Arpaci, I., Karataş, K., \& Baloğlu, M. (2020). The development and initial tests for the psychometric properties of the COVID-19 Phobia Scale (C19P-S) [Article]. Personality and Individual Differences, 164, Article 110108. https://doi.org/10.1016/j.paid.2020.110108

Chandu, V. C., Pachava, S., Vadapalli, V., \& Marella, Y. (2020). Development and Initial Validation of the COVID-19 Anxiety Scale [Article]. Indian journal of public health, 64, S201-S204. https://doi.org/10.4103/ijph.IJPH_492_20

da Silva, F. C. T., \& Neto, M. L. R. (2021). Psychiatric symptomatology associated with depression, anxiety, distress, and insomnia in health professionals working in patients affected by COVID-19: A systematic review with meta-analysis [Article]. Progress in Neuro-Psychopharmacology and Biological Psychiatry, 104, Article 110057. https://doi.org/10.1016/j.pnpbp.2020.110057

Daly, M., Sutin, A. R., \& Robinson, E. (2021). Depression reported by US adults in 2017-2018 and March and April 2020 [Article]. Journal of Affective Disorders, 278, 131-135. https://doi.org/10.1016/j.jad.2020.09.065

Evren, C., Evren, B., Dalbudak, E., Topcu, M., \& Kutlu, N. (2020). Measuring anxiety related to COVID19: A Turkish validation study of the Coronavirus Anxiety Scale [Article]. Death Studies. https://doi.org/10.1080/07481187.2020.1774969

Feng, L. S., Dong, Z. J., Yan, R. Y., Wu, X. Q., Zhang, L., Ma, J., \& Zeng, Y. (2020). Psychological distress in the shadow of the COVID-19 pandemic: Preliminary development of an assessment 
scale [Article]. Psychiatry Research, 291, Article 113202.

https://doi.org/10.1016/j.psychres.2020.113202

Lee, S. A. (2020). Coronavirus Anxiety Scale: A brief mental health screener for COVID-19 related anxiety [Article]. Death Studies, 44(7), 393-401. https://doi.org/10.1080/07481187.2020.1748481

Lee, S. A., Mathis, A. A., Jobe, M. C., \& Pappalardo, E. A. (2020). Clinically significant fear and anxiety of COVID-19: A psychometric examination of the Coronavirus Anxiety Scale [Article]. Psychiatry Research, 290, Article 113112. https://doi.org/10.1016/j.psychres.2020.113112

Muris, P., Schmidt, H., \& Merckelbach, H. (1999). The structure of specific phobia symptoms among children and adolescents. Behaviour research and therapy, 37(9), 863-868.

Pakpour, A. H., Griffiths, M. D., \& Lin, C. Y. (2020). Assessing Psychological Response to the COVID-19: The Fear of COVID-19 Scale and the COVID Stress Scales [Letter]. International Journal of Mental Health and Addiction. https://doi.org/10.1007/s11469-020-00334-9

Reznik, A., Gritsenko, V., Konstantinov, V., Khamenka, N., \& Isralowitz, R. (2020). COVID-19 Fear in Eastern Europe: Validation of the Fear of COVID-19 Scale [Note]. International Journal of Mental Health and Addiction. https://doi.org/10.1007/s11469-020-00283-3

Ruiz-Frutos, C., Ortega-Moreno, M., Allande-Cussó, R., Domínguez-Salas, S., Dias, A., \& GómezSalgado, J. (2021). Health-related factors of psychological distress during the COVID-19 pandemic among non-health workers in Spain [Article]. Safety Science, 133, Article 104996. https://doi.org/10.1016/j.ssci.2020.104996

e COVID-19 outbreak (2020) Psychiatry Res., 288, p. 112958

Satici, B., Gocet-Tekin, E., Deniz, M. E., \& Satici, S. A. (2020). Adaptation of the Fear of COVID-19 Scale: Its Association with Psychological Distress and Life Satisfaction in Turkey [Article]. International Journal of Mental Health and Addiction. https://doi.org/10.1007/s11469-020-00294-0

Soraci, P., Ferrari, A., Abbiati, F. A., Del Fante, E., De Pace, R., Urso, A., \& Griffiths, M. D. (2020). Validation and Psychometric Evaluation of the Italian Version of the Fear of COVID-19 Scale [Article]. International Journal of Mental Health and Addiction. https://doi.org/10.1007/s11469020-00277-1

Sumintono, B., \& Widhiarso, W. (2014). Aplikasi model Rasch untuk penelitian ilmu-ilmu sosial (edisi revisi). Trim Komunikata Publishing House.

Yıldırım, M., \& Güler, A. (2020). Factor analysis of the COVID-19 Perceived Risk Scale: A preliminary study [Article]. Death Studies. https://doi.org/10.1080/07481187.2020.1784311

Zhong, B., Huang, Y., \& Liu, Q. (2021). Mental health toll from the coronavirus: Social media usage reveals Wuhan residents' depression and secondary trauma in the COVID-19 outbreak [Article]. Computers in Human Behavior, 114, Article 106524. https://doi.org/10.1016/j.chb.2020.106524

\section{Competing interests:}

The authors declare that they have no significant competing financial, professional or personal interests that might have influenced the performance or presentation of the work described in this manuscript. 
480 Providing a psychological scale to measure COVID-19 phobia in the Indonesian version: a brief report on validation of C19P$\mathrm{S}$ via Rasch Analysis

\section{Appendix I : Rating Scale Analysis}

SUMMARY OF CATEGORY STRUCTURE. MOdel="R"

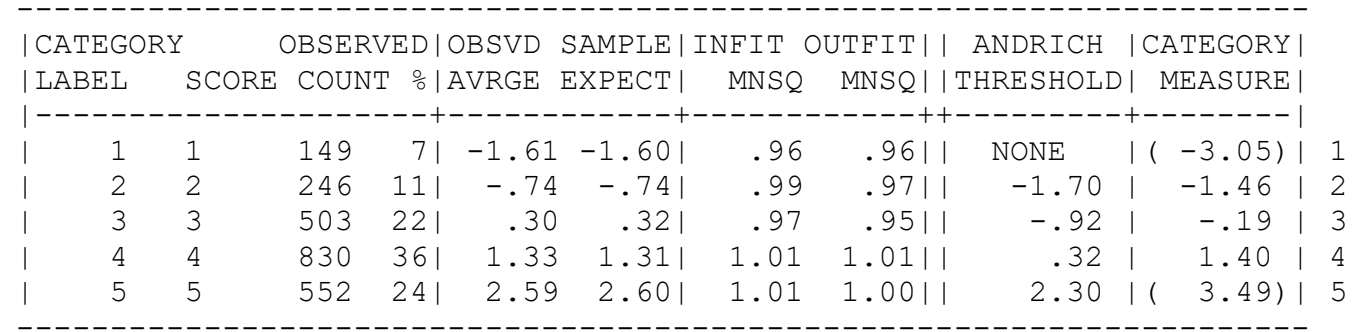

OBSERVED AVERAGE is mean of measures in category. It is not a parameter estimate.

\begin{tabular}{|c|c|c|c|c|c|c|c|c|c|c|}
\hline \multirow{3}{*}{$\begin{array}{l}\text { CATEGORY } \\
\text { LABEL }\end{array}$} & \multicolumn{2}{|c|}{ STRUCTURE } & \multicolumn{3}{|c|}{ I SCORE-TO-MEASURE } & \multirow{2}{*}{$\begin{array}{l}\text { 50\% CUM. | } \\
\text { | PROBABLTY| }\end{array}$} & \multicolumn{2}{|c|}{ COHERENCE } & \multicolumn{2}{|r|}{ | ESTIM $\mid$} \\
\hline & MEASURE & S.E. & I AT CAT. & $----Z C$ & $N E----1$ & & $M->C$ & $\mathrm{C}->\mathrm{M}$ & RMSR & $|\mathrm{DISCR}|$ \\
\hline & & & & & & & & & & \\
\hline 1 & NONE & & $\mid(-3.05)$ & $-I N F$ & $-2.31 \mid$ & & $67 \%$ & $19 \%$ & 1.0923 & \\
\hline 2 & -1.70 & .10 & -1.46 & -2.31 & -.821 & -2.01 & $40 \%$ & $46 \%$ & .9167 & $|1.03|$ \\
\hline 3 & -.92 & .08 & -.19 & -.82 & .521 & -.85 & $43 \%$ & $42 \%$ & .7240 & $|1.01|$ \\
\hline 4 & .32 & .06 & 1.40 & .52 & 2.581 & .43 & $51 \%$ & $69 \%$ & .5376 & $1.04 \mid$ \\
\hline 5 & 2.30 & .06 & $\left(\begin{array}{l}(3.49) \\
3\end{array}\right.$ & 2.58 & $+\mathrm{INF}$ & 2.42 & $72 \%$ & $43 \%$ & .7474 & $.97 \mid$ \\
\hline
\end{tabular}

$\mathrm{M}->\mathrm{C}=$ Does Measure imply Category?

$\mathrm{C}->\mathrm{M}=$ Does Category imply Measure?

\section{Appendix II : Person Measure Order} $\begin{array}{llll}\text { TABLE } 17.1 & \text { Olah Data Fiks.xlsx } & \text { ZOU656WS.TXT Feb } 192021 & 15: 37 \\ \text { INPUT: } 220 & \text { PERSON } 20 \text { ITEM REPORTED: } 120 \text { PERSON } 19 \text { ITEM 5 CATS WINSTEPS 4.8.0.0 }\end{array}$ PERSON: REAL SEP.: 3.07 REL.: .90 ... ITEM: REAL SEP.: 8.82 REL.: .99 PERSON STATISTICS: MEASURE ORDER

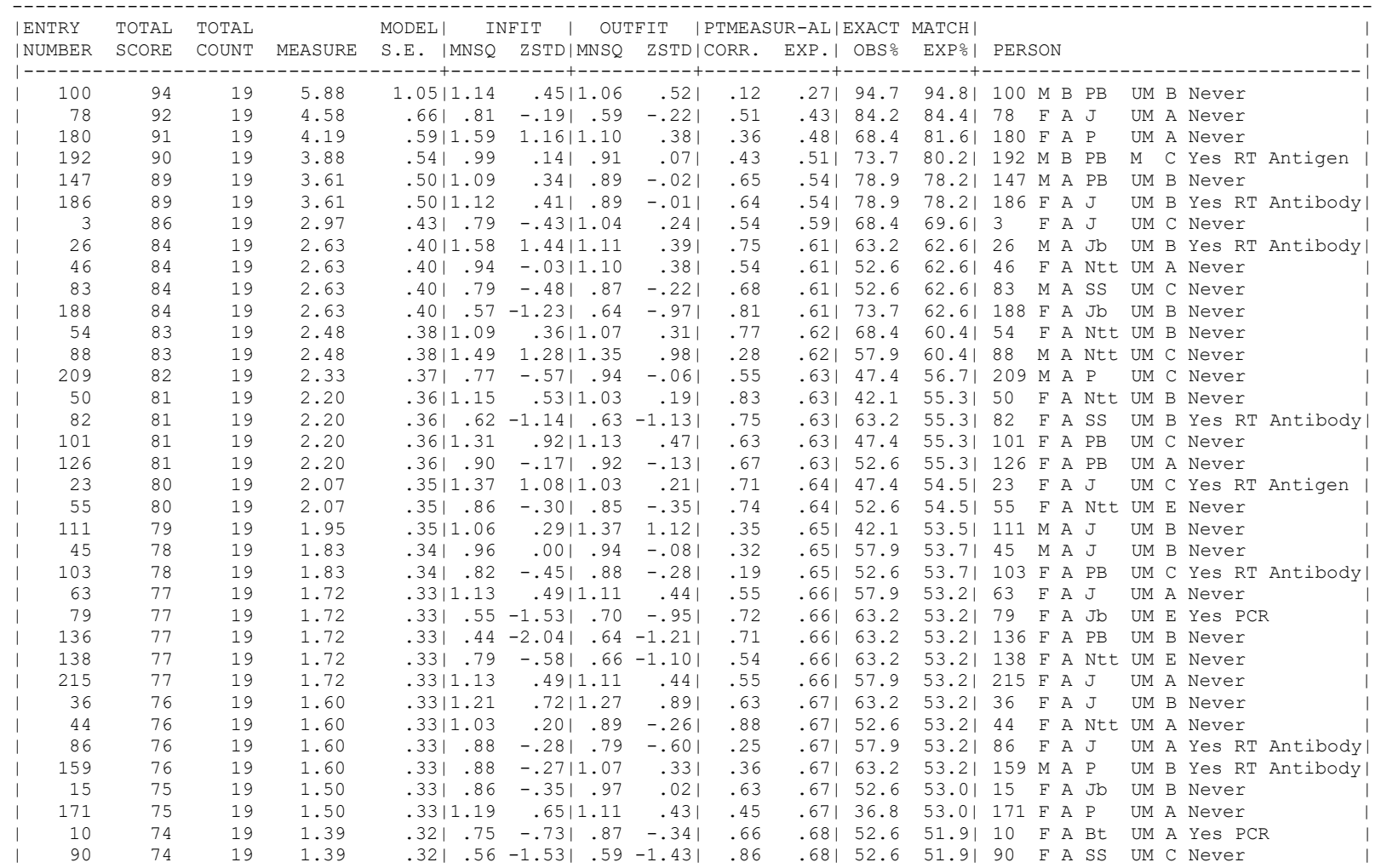




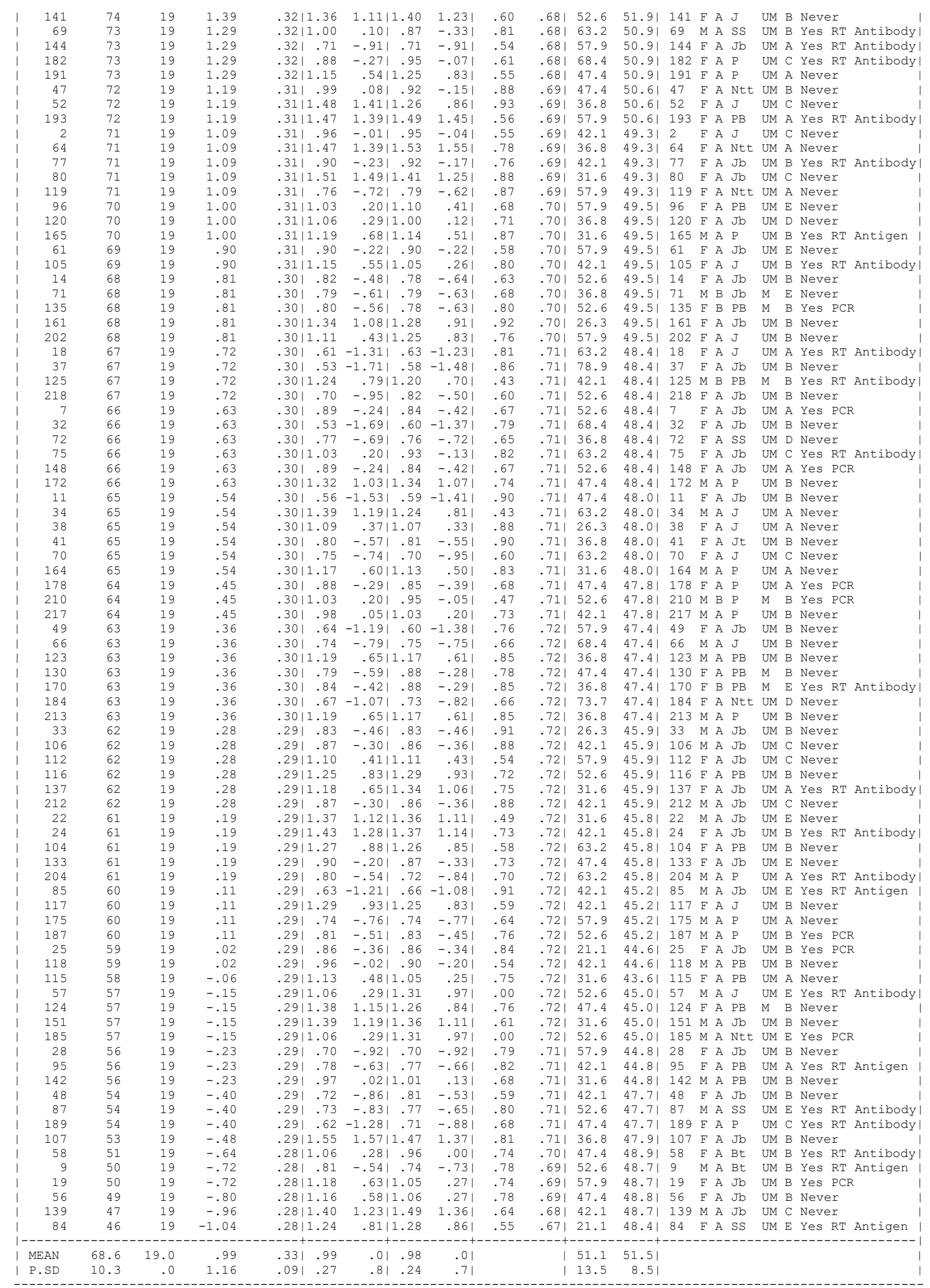

